\title{
HAEMATOLOGICAL INDICES IN FALLOW DEER
}

\author{
G. KOVÁČ. J. CIBEREJ. I. PAULÍKOVÁ. H. SEIDEL \\ Department of Internal Diseases of Ruminants and Swine, \\ University of Veterinary Medicine, Košice. Slovak Republic
}

Received July 11, 1997

Accepted January 15, 1998

\begin{abstract}
G. Kováč, J. Ciberej. I. Paulíková, H. Seidel: Haematological Indices in Fallow Deer. Acta vet. Brno, 1997, 66: 203-211.

Dynamics of haematological indices (erythrocytes, leukocytes, haemoglobin. haematocrit. segmented and band neutrophils, eosinophils. basophils. lymphocytes, and monocytes) were studied in 11 male and 19 female fallow deer. The animals were shot at the game parks Rozhanovce and Rožňava-Betliar.

Average values of haematological indices in juvenile (younger than 2 years) and adult (over two years) fallow deer were as follows: $\mathrm{Er}-10.95$ and $9.84 \mathrm{~T} / \mathrm{l}$ : $\mathrm{Lc}-3.98$ and $3.55 \mathrm{G} / \mathrm{l} ; \mathrm{Hb}-13.12$ and $13.08 \mathrm{~g} / \mathrm{dl}: \mathrm{Hc}-0.48$ and $0.49 \mathrm{l} / \mathrm{l}: \mathrm{Ns}-39.5$ and $40.5 \% ; \mathrm{Nb}-4.5$ and $6.4 \%$ : Eo -5.2 and $3.7 \% ; \mathrm{Ba}$ -0 and $0.2 \% ; \mathrm{Ly}-49.3$ and $49.3 \%$; and Mo -1.3 and $0.7 \%$, respectively. The differences between young and adult animals were not significant.

Similarly, no significant differences were recorded in the juvenile fallow deer when evaluated by their gender. On the other hand. in adult animals significant $(\mathrm{P}<0.05)$ differences were observed between male and female animals in $\mathrm{Hb}(11.07$ and $13.89 \mathrm{~g} / \mathrm{dl}$, resp.) and hematocrit $(0.43$ and $0.51 \mathrm{l} / \mathrm{l}$. resp.).

Seasonal changes were as follows $(\mathrm{P}<0.05)$ : Er spring-autumn (average values 11.24 and 8.38 T/1. resp.), spring-winter (11.24 and 9.49 T/1); Lc spring-winter (3.97 and $2.5 \mathrm{G} / \mathrm{l}$ ), summer-winter ( 4.64 and $2.50 \mathrm{G} / \mathrm{l})$, and autumn-winter $(5.53$ and $2.50 \mathrm{G} / \mathrm{l})$; $\mathrm{Hb}$ spring-summer ( 13.65 and $11.42 \mathrm{~g} / \mathrm{dl})$. spring-autumn ( 13.65 and $9.70 \mathrm{~g} / \mathrm{dl})$. summer-winter $(11.42$ and $14.17 \mathrm{~g} / \mathrm{dl})$. and autumn-winter $(9.70$ and $14.17 \mathrm{~g} / \mathrm{dl})$; $\mathrm{Hc}$ spring-summer $(0.50$ and $0.42 \mathrm{l} / \mathrm{l})$, summer-winter $(0.42$ and $0.53 \mathrm{l} / \mathrm{l})$, autumn-winter $(0.44$ and $0.53 \mathrm{l} / \mathrm{l})$; $\mathrm{Nb}$ spring-summer $(2.8$ and $8.0 \%)$. spring-autumn $(2.8$ and $6.6 \%)$, summer-winter $(8.0$ and $4.3 \%$ ): Ly spring-winter $(53.1$ and $47.0 \%)$; Mo spring-winter $(2.2$ and $0.2 \%)$. These findings indicate a transition period in feeding. In winter. there is an increased proportion of dry matter in the diet due to nipping off tree twigs. and feeding hay and other dried foods. The change from winter to spring feeding is related to feeding green pasture-grasses and winter corns. As in domesticated ruminants, it may be suggested that there is a period of adaptation of rumen microflora and microfauna. This period is frequently associated with diarrhoea. which may cause the changes in haematological profile.
\end{abstract}

Fallow deer, age, gender, season of the year, erythrocytes, leukocytes, haemoglobin. haematocrit

Health management and production potential of livestock is closely related to application of effective diagnostic and preventive measures. Rearing of fallow deer in game parks, farms. and free nature is of increasing importance. Moreover, game animals serve as a valuable bioindicator of environment quality (Mlynarčíková et al. 1995; Legáth et al. 1996). Therefore, clinical examination and metabolic tests (haematological. macro- and micro-elements, enzymatic, protein, energetic. vitamin. ruminal, and urinary profiles) in fallow deer are also inevitable to obtain a complex evaluation of their environment (including nutrition).

By this approach, it is possible to detect metabolic disorders (lack or surplus of energy, protein. macro- and micro-elements) and increased exposure to risk elements in industrial areas or areas with high level of chemization.

Archaeological findings indicate the presence of fallow deer in Middle Europe in the past two inter-glacial ages. During the last glacial age. fallow deer disappeared from this region. Spotted fallow deer (Dama dama Linné 1785) survived in Middle Asia. particularly in 
Taurus mountains (present Turkey) and the island of Rhodos in Mediterranean Sea. Mesopotamic fallow deer (Dama mesopotamica Brooke, 1885), the relative of spotted fallow deer, was described only 110 years ago in border regions of Iran and Iraq. Spotted fallow deer was reintroduced to Europe with Roman legions. To the territory of Slovakia, fallow deer was introduced probably in the 13th century during establishment of new royal game parks at Zvolen and Gemer regions. Contrary to endangered Mesopotamic fallow deer, world population of spotted fallow deer is about 200000 animals (Heideman 1987). Following the preceding reports on fallow deer populations in England and Germany, Randi and Apollonio (1988) confirmed low variability in biochemical indices of the European population of fallow deer.

The aim of the present work was to complete the existing data, and compare juvenile and adult animals. We further studied their biochemical indices during four seasons of the year.

\section{Materials and Methods}

The studies were performed at a facility of the UVM Košice (game park Rozhanovce, 501 ha, 0.45 animal per ha) and game park Betliar (1 298 ha, 0.49 animal per ha) in Eastern Slovakia during the years 1993-1995. The fallow deer population at Rozhanovce came from Hungarian Guylai Farm; the Betliar population is mostly of hybrid origin.

During one year (January-December), fallow deer (11 males and 19 females) were shot dead. Blood was collected immediately from jugular vein into beakers with anticoagulant $\left(\mathrm{K}_{3}\right.$ EDTA) for haematological examination.

The blood samples were analysed within 12 hours using standard haematological equipment. Values of ery throcytes (Er), leukocytes ( $\mathrm{Lc})$, haemoglobin $(\mathrm{Hb})$, and haematocrit $(\mathrm{Hc})$ were measured by cell counter (Serono 150+ Analyser). Differential leukocyte count (segmented neutrophils - Ns, band neutrophils - Nb, eosinophils - Eo, basophils - Ba, lymphocytes - Ly, and monocytes - Mo) were determined microscopically on blood smears stained by Pappenheim (Slanina et al. 1993).

The results are presented as mean values (x), sum of values, minimal and maximal values, standard deviation (SD), and standard error of mean (SEM). Student's t-test was used to assess the differences between the groups (Excel 5.0).

\section{Results}

The animals were divided into two groups: juvenile fallow deer - aged up to 2 years, and adult animals - older than 2 years. These groups were evaluated by their gender, male and female; and season of the year, i.e. spring, summer, autumn, and winter. The results are presented in Tables 1-10.

Table 1

Haematological indices in fallow deer

(juvenile animals, $\mathrm{n}=16$ )

\begin{tabular}{|c|c|c|c|c|c|c|c|c|c|c|}
\hline & $\begin{array}{r}\mathrm{Er} \\
\mathrm{T} / 1\end{array}$ & $\begin{array}{r}\mathrm{Lc} \\
\mathrm{G} / 1\end{array}$ & $\begin{array}{r}\mathrm{Hb} \\
\mathrm{g} / \mathrm{dl}\end{array}$ & $\begin{array}{l}\mathrm{Hc} \\
\quad 1 / 1\end{array}$ & $\begin{array}{r}\text { Ns } \\
\%\end{array}$ & $\begin{array}{r}\mathrm{Nb} \\
\%\end{array}$ & $\begin{array}{r}\text { Eo } \\
\%\end{array}$ & $\begin{array}{r}\mathrm{Ba} \\
\%\end{array}$ & $\begin{array}{r}\text { Ly } \\
\%\end{array}$ & $\begin{array}{r}\text { Mo } \\
\%\end{array}$ \\
\hline $\mathrm{x}$ & 10.95 & 3.98 & 13.12 & 0.48 & 39.5 & 4.5 & 5.2 & 0 & 49.3 & 1.3 \\
\hline sum & 175.2 & 63.7 & 210.0 & 7.71 & 633 & 72 & 84 & 0 & 789 & 21 \\
\hline min. & 6.48 & 2.00 & 6.9 & 0.38 & 19 & 0 & 0 & 0 & 38 & 0 \\
\hline $\max$. & 13.80 & 8.7 & 16.5 & 0.58 & 50 & 28 & 18 & 0 & 64 & 4 \\
\hline SD & 2.05 & 1.48 & 2.35 & 0.05 & 8.7 & 6.7 & 5.0 & 0 & 7.3 & 1.2 \\
\hline SEM & 0.54 & 0.37 & 0.58 & 0.01 & 2.1 & 1.6 & 1.2 & 0 & 1.8 & 0.3 \\
\hline
\end{tabular}


Table 2

Haematological indices in fallow deer

(adult animals, $n=14$ )

\begin{tabular}{|l|c|c|c|c|c|c|c|c|c|c|}
\hline & $\begin{array}{c}\mathrm{Er} \\
\mathrm{T} / 1\end{array}$ & $\begin{array}{c}\mathrm{Lc} \\
\mathrm{G} / 1\end{array}$ & $\begin{array}{c}\mathrm{Hb} \\
\mathrm{g} / \mathrm{dl}\end{array}$ & $\begin{array}{c}\mathrm{Hc} \\
\mathrm{I} / 1\end{array}$ & $\begin{array}{c}\mathrm{Ns} \\
\%\end{array}$ & $\begin{array}{c}\mathrm{Nb} \\
\%\end{array}$ & $\begin{array}{c}\mathrm{Eo} \\
\%\end{array}$ & $\begin{array}{c}\mathrm{Ba} \\
\%\end{array}$ & $\begin{array}{c}\mathrm{Ly} \\
\%\end{array}$ & $\begin{array}{c}\mathrm{Mo} \\
\%\end{array}$ \\
\hline $\mathrm{x}$ & 9.84 & 3.55 & 13.08 & 0.49 & 40.5 & 6.4 & 3.7 & 0.2 & 49.1 & 0.7 \\
\hline sum & 137.78 & 49.70 & 183.20 & 6.96 & 567 & 90 & 52 & 3 & 642 & 10 \\
\hline $\min$. & 8.38 & 2.0 & 9.2 & 0.36 & 34 & 0 & 1 & 0 & 39 & 0 \\
\hline $\max$. & 12.12 & 8.6 & 15.5 & 0.58 & 50 & 10 & 8 & 1 & 55 & 4 \\
\hline $\mathrm{SD}$ & 1.36 & 1.59 & 2.08 & 0.07 & 5.3 & 2.4 & 2.3 & 0.4 & 4.1 & 1.3 \\
\hline SEM & 0.36 & 0.42 & 0.55 & 0.01 & 1.4 & 0.6 & 0.6 & 0.1 & 1.1 & 0.3 \\
\hline
\end{tabular}

We observed non-significant differences between young and adult fallow deer animals in all indices of the haematological profile.

Table 3

Haematological profile in fallow deer (juvenile males, $\mathrm{n}=7$ )

\begin{tabular}{|l|c|c|c|c|c|c|c|c|c|c|}
\hline & $\begin{array}{c}\mathrm{Er} \\
\mathrm{T} / 1\end{array}$ & $\begin{array}{c}\mathrm{Lc} \\
\mathrm{G} / 1\end{array}$ & $\begin{array}{c}\mathrm{Hb} \\
\mathrm{g} / \mathrm{dl}\end{array}$ & $\begin{array}{c}\mathrm{Hc} \\
1 / 1\end{array}$ & $\begin{array}{c}\mathrm{Ns} \\
\%\end{array}$ & $\begin{array}{c}\mathrm{Nb} \\
\%\end{array}$ & $\begin{array}{c}\mathrm{Eo} \\
\%\end{array}$ & $\begin{array}{c}\mathrm{Ba} \\
\%\end{array}$ & $\begin{array}{c}\mathrm{Ly} \\
\%\end{array}$ & $\begin{array}{c}\mathrm{Mo} \\
\%\end{array}$ \\
\hline $\mathrm{x}$ & 10.08 & 4.14 & 12.47 & 0.47 & 42.5 & 3.0 & 3.7 & 0 & 48.8 & 1.7 \\
\hline sum & 70.57 & 29.00 & 87.3 & 3.32 & 298 & 21 & 26 & 0 & 342 & 12 \\
\hline $\min$. & 6.48 & 2.0 & 6.9 & 0.38 & 36 & 0 & 0 & 0 & 44 & 0 \\
\hline $\max$. & 12.36 & 8.7 & 15.0 & 0.56 & 49 & 6 & 11 & 0 & 53 & 3 \\
\hline SD & 2.54 & 2.23 & 2.87 & 0.06 & 4.9 & 2.3 & 3.5 & 0 & 3.2 & 0.9 \\
\hline SEM & 0.96 & 0.84 & 1.08 & 0.02 & 1.8 & 0.8 & 1.3 & 0 & 1.2 & 0.3 \\
\hline
\end{tabular}

Table 4

Haematological profile in fallow deer (juvenile females, $n=9$ )

\begin{tabular}{|l|c|c|c|c|c|c|c|c|c|c|}
\hline & $\begin{array}{c}\mathrm{Er} \\
\mathrm{T} / 1\end{array}$ & $\begin{array}{c}\mathrm{Lc} \\
\mathrm{G} / 1\end{array}$ & $\begin{array}{c}\mathrm{Hb} \\
\mathrm{g} / \mathrm{dl}\end{array}$ & $\begin{array}{c}\mathrm{Hc} \\
1 / 1\end{array}$ & $\begin{array}{c}\mathrm{Ns} \\
\%\end{array}$ & $\begin{array}{c}\mathrm{Nb} \\
\%\end{array}$ & $\begin{array}{c}\mathrm{Eo} \\
\%\end{array}$ & $\begin{array}{c}\mathrm{Ba} \\
\%\end{array}$ & $\begin{array}{c}\mathrm{Ly} \\
\%\end{array}$ & $\begin{array}{c}\text { Mo } \\
\%\end{array}$ \\
\hline $\mathrm{x}$ & 11.57 & 3.85 & 13.63 & 0.48 & 37.2 & 5.6 & 6.4 & 0 & 49.6 & 1 \\
\hline sum & 104.18 & 34.70 & 122.70 & 4.39 & 335 & 51 & 58 & 0 & 447 & 9 \\
\hline $\min$. & 9.46 & 3.0 & 10.7 & 0.39 & 19 & 0 & 2 & 0 & 38 & 0 \\
\hline $\max$. & 13.80 & 4.5 & 16.5 & 0.58 & 50 & 28 & 18 & 0 & 64 & 4 \\
\hline SD & 1.56 & 0.56 & 1.88 & 0.05 & 10.4 & 8.8 & 5.9 & 0 & 9.5 & 1.4 \\
\hline SEM & 0.52 & 0.18 & 0.62 & 0.01 & 3.4 & 2.9 & 1.9 & 0 & 3.1 & 0.4 \\
\hline
\end{tabular}

Statistically non-significant differences in all haematological indices were observed between juvenile male and female fallow deer animals. 
Table 5

Haematological profile in fallow deer (adult males, $n=4$ )

\begin{tabular}{|l|c|c|c|c|c|c|c|c|c|c|}
\hline & $\begin{array}{c}\mathrm{Er} \\
\mathrm{T} / 1\end{array}$ & $\begin{array}{c}\mathrm{Lc} \\
\mathrm{G} / 1\end{array}$ & $\begin{array}{c}\mathrm{Hb} \\
\mathrm{g} / \mathrm{dl}\end{array}$ & $\begin{array}{c}\mathrm{Hc} \\
1 / 1\end{array}$ & $\begin{array}{c}\mathrm{Ns} \\
\%\end{array}$ & $\begin{array}{c}\mathrm{Nb} \\
\%\end{array}$ & $\begin{array}{c}\text { Eo } \\
\%\end{array}$ & $\begin{array}{c}\mathrm{Ba} \\
\%\end{array}$ & $\begin{array}{c}\mathrm{Ly} \\
\%\end{array}$ & $\begin{array}{c}\text { Mo } \\
\%\end{array}$ \\
\hline $\mathrm{x}$ & 9.05 & 3.77 & $11.0^{\mathrm{a}}$ & $0.43^{\mathrm{b}}$ & 38.7 & 8.2 & 4.2 & 0.5 & 48 & 0.2 \\
\hline sum & 36.20 & 15.10 & 44.30 & 1.72 & 155 & 33 & 17 & 2 & 192 & 1 \\
\hline min. & 8.86 & 3.4 & 10.6 & 0.36 & 36 & 6 & 2 & 0 & 45 & 0 \\
\hline $\max$. & 9.24 & 4.2 & 11.6 & 0.48 & 43 & 10 & 8 & 1 & 51 & 1 \\
\hline $\mathrm{SD}$ & 0.17 & 0.33 & 0.45 & 0.05 & 3.4 & 1.7 & 2.6 & 0.5 & 2.9 & 0.5 \\
\hline $\mathrm{SEM}$ & 0.08 & 0.16 & 0.22 & 0.02 & 1.7 & 0.8 & 1.3 & 0.2 & 1.4 & 0.2 \\
\hline
\end{tabular}

No significant differences were found between male and female animals in $\mathrm{Er}, \mathrm{Lc}$. Ns, $\mathrm{Nb}$, Eo, Ba, Ly, and Mo. However, significant differences $(\mathrm{P}<0.5)$ were observed in $\mathrm{Hb}^{\mathrm{a}}$ and $\mathrm{Hc}^{\mathrm{b}}$ between these two groups.

Regarding the season of the year, we observed the following significant $(\mathrm{P}<0.05)$ differences of haematological indices: $\mathrm{Er}$ - spring:autumn ${ }^{\mathrm{c}}$, spring:winter ${ }^{\mathrm{c}}$; Lc spring:winter ${ }^{\mathrm{d}}$, summer:winter ${ }^{\mathrm{d}}$, autumn:winter ${ }^{\mathrm{d}} ; \mathrm{Hb}$ - spring:summer $^{\mathrm{e}}$, spring:autumn ${ }^{\mathrm{e}}$, summer:winter ${ }^{\mathrm{e}}$, autumn: inter $^{\mathrm{e}} ; \mathrm{Hc}$ - spring:summer ${ }^{\mathrm{f}}$, summer:winter ${ }^{\mathrm{f}}$, autumn:winter ${ }^{\mathrm{f}}$; $\mathrm{Nb}$ - spring:summer ${ }^{\mathrm{g}}$, spring:autumng, summer:winter ${ }^{\mathrm{g}}$; Ly - spring:winter ${ }^{\mathrm{h}}$; Mo spring:winter ${ }^{\mathrm{ch}}$. There were no significant seasonal differences in Ns, Eo, and Ba.

\section{Discussion}

Rearing and improvement of wild animals requires careful management of their environment (biotope, composition of food, water sources, etc.) as well as biochemical indices of the animals (haematological, macro- and micro-elements, needs for energy, protein, etc.)

There are numerous literature data on domesticated and wild animals. In these studies, various points of view were used such as animal species, genus, age, gender, season of the year (closely related to qualitative and quantitative nutritional changes), stage of pregnancy, immobilization methods, catching, keeping, shooting, etc. (Vrzgula et al. 1991; Kováč et al. 1986; Slanina et al. 1993; Jelínek et al. 1984; Abaigar 1993; Kocan et al. 1981; Silva et al. 1993a; Reitkerk et al. 1994; Váhala et al. 1994; Wolkers et al. 1994).

Table 6

Haematological profile in fallow deer (adult females, $\mathrm{n}=10$ )

\begin{tabular}{|l|c|c|c|c|c|c|c|c|c|c|}
\hline & $\begin{array}{c}\mathrm{Er} \\
\mathrm{T} / 1\end{array}$ & $\begin{array}{c}\mathrm{Lc} \\
\mathrm{G} / 1\end{array}$ & $\begin{array}{c}\mathrm{Hb} \\
\mathrm{g} / \mathrm{dl}\end{array}$ & $\begin{array}{c}\mathrm{Hc} \\
1 / 1\end{array}$ & $\begin{array}{c}\mathrm{Ns} \\
\%\end{array}$ & $\begin{array}{c}\mathrm{Nb} \\
\%\end{array}$ & $\begin{array}{c}\text { Eo } \\
\%\end{array}$ & $\begin{array}{c}\mathrm{Ba} \\
\%\end{array}$ & $\begin{array}{c}\mathrm{Ly} \\
\%\end{array}$ & $\begin{array}{c}\mathrm{Mo} \\
\%\end{array}$ \\
\hline $\mathrm{x}$ & 10.15 & 3.46 & $13.8^{\mathrm{a}}$ & $0.51^{\mathrm{b}}$ & 41.2 & 5.7 & 3.5 & 0.1 & 49.6 & 0.9 \\
\hline sum & 101.58 & 34.60 & 138.90 & 5.14 & 412 & 57 & 35 & 1 & 496 & 9 \\
\hline $\min$. & 8.38 & 2.0 & 9.2 & 0.38 & 34 & 0 & 1 & 0 & 39 & 0 \\
\hline $\max$. & 12.12 & 8.6 & 15.5 & 0.58 & 50 & 8 & 8 & 1 & 55 & 4 \\
\hline $\mathrm{SD}$ & 1.50 & 1.90 & 1.92 & 0.06 & 5.9 & 2.3 & 2.2 & 0.3 & 4.5 & 1.5 \\
\hline SEM & 0.47 & 0.60 & 0.60 & 0.02 & 1.8 & 0.7 & 0.7 & 0.1 & 1.4 & 0.4 \\
\hline
\end{tabular}


During our one year study, assessment of haematological indices in fallow deer showed increased average values of erythrocytes, haemoglobin and haematocrit compared to reference values in cattle (young and adult fallow deer population: $\mathrm{Er}-10.95$ and $9.84 \mathrm{~T} /$; $\mathrm{Hb}-13.12$ and $13.08 \mathrm{~g} / \mathrm{dl} ; \mathrm{Hc}-0.48$ and $0.49 \mathrm{l} / \mathrm{l}$, respectively; compared with cattle reference values: $\mathrm{Er}-5.1-7.9 \mathrm{~T} / \mathrm{l}, \mathrm{Hb}-9.3-11.7 \mathrm{~g} / \mathrm{dl}, \mathrm{Hc}-0.30-0.40 \mathrm{l} / \mathrm{l})$. These findings may be related to stress during capture. restraint, or shooting of the animals (as reported in previous articles - Cimbal et al. 1985, 1990). It is associated with adrenaline-mediated contraction of the spleen (Wilson and Pauli 1982). Other possible explanation may be physiological adaptation in connection with sudden reaction in the form of escape from the place of danger. According to Mautz et al. (1980) and Kocan et al. (1981) chemical and physical immobilization had no effects on haematological indices in white-tailed deer.

In young fallow deer, comparing values after birth and at three months of age, we found (Cimbal et al. 1990) an increase in $\mathrm{Er}, \mathrm{Hb}$, and $\mathrm{Hc}$ (Er - from 7.87 to $11.99 \mathrm{~T} / \mathrm{l} ; \mathrm{Hb}-$ from 8.68 to $11.05 \mathrm{~g} / \mathrm{dl} ; \mathrm{Hc}$ - from 0.34 to $0.49 \mathrm{l} / \mathrm{l}$ ). This is probably associated with development and function ability of haematopoietic system at an early age. Chapman (1977) reported age differences in red blood cell indices. In the young, these indices reached the values of adult animals approximately at 6 months of age (determined also in white-tailed deer and mountain roebuck).

Table 7

Haematological profile in fallow deer

(spring 21.3.-20.6., $\mathrm{n}=10$ )

\begin{tabular}{|l|c|c|c|c|c|c|c|c|c|c|}
\hline & $\begin{array}{c}\mathrm{Er} \\
\mathrm{T} / \mathrm{l}\end{array}$ & $\begin{array}{c}\mathrm{Lc} \\
\mathrm{G} / 1\end{array}$ & $\begin{array}{c}\mathrm{Hb} \\
\mathrm{g} / \mathrm{dl}\end{array}$ & $\begin{array}{c}\mathrm{Hc} \\
\mathrm{l} / 1\end{array}$ & $\begin{array}{c}\mathrm{Ns} \\
\%\end{array}$ & $\begin{array}{c}\mathrm{Nb} \\
\%\end{array}$ & $\begin{array}{c}\mathrm{Eo} \\
\%\end{array}$ & $\begin{array}{c}\mathrm{Ba} \\
\%\end{array}$ & $\begin{array}{c}\mathrm{Ly} \\
\%\end{array}$ & $\begin{array}{c}\mathrm{Mo} \\
\%\end{array}$ \\
\hline $\mathrm{x}$ & $11.24^{\mathrm{c}}$ & $3.97^{\mathrm{d}}$ & $13.65^{\mathrm{e}}$ & $0.50^{\mathrm{f}}$ & 38.1 & $2.8^{\mathrm{g}}$ & 3.8 & 0 & $53.1^{\mathrm{h}}$ & $2.2^{\mathrm{ch}}$ \\
\hline sum & 101.20 & 39.70 & 136.50 & 5.00 & 381 & 28 & 38 & 0 & 531 & 22 \\
\hline $\min$. & 9.46 & 2.9 & 10.7 & 0.39 & 22 & 0 & 1 & 0 & 40 & 0 \\
\hline $\max$ & 12.12 & 5.0 & 15.5 & 0.58 & 50 & 6 & 10 & 0 & 64 & 4 \\
\hline $\mathrm{SD}$ & 0.94 & 0.64 & 1.68 & 0.06 & 7.7 & 2.3 & 2.9 & 0 & 7.0 & 1.3 \\
\hline $\mathrm{SEM}$ & 0.31 & 0.20 & 0.53 & 0.01 & 2.4 & 0.7 & 0.9 & 0 & 2.2 & 0.4 \\
\hline
\end{tabular}

In this report we observed no statistically significant differences in the above mentioned indices within the one year study of comparison between juvenile (younger than 2 years) and adult (older than 2 years) fallow deer. Similarly, we recorded no significant difference between the male and female juvenile anima1s. On the other hand, in the adult population there were significant differences in $\mathrm{Hb}$ and $\mathrm{Hc}$ related to gender with higher average values in females. Chapman and Chapman (1982) observed no significant differences in $\mathrm{Hb}, \mathrm{Er}$, and $\mathrm{Hc}$ in relation to age and sex of fallow deer. However, in our study, values in females were markedly higher than in males. We suggest that in the fallow deer population older than 2 years these differences may be caused by effects of year season and gender.

Regarding the white blood picture, as reported in previous studies (Cimbal et al. 1986), after catching of fallow deer there are substantially lower numbers of leukocytes compared with domesticated ruminants (young and adult fallow deer: Lc - 3.98 and $3.65 \mathrm{G} / \mathrm{l}$, resp.; cattle below 3 months - 6.2 - $11.0 \mathrm{G} / 1$; adult cattle - 6.0 - $10.0 \mathrm{G} / 1$; sheep - 5.1 - $11.1 \mathrm{G} / 1$; goats $-8.8-14.3 \mathrm{G} / 1)$. However, these findings are not indicative of clinical leukopenia. It is 
Table 8

Haematological profile in fallow deer

(summer 21.6.-22.9.. $\mathrm{n}=5$ )

\begin{tabular}{|l|c|c|c|c|c|c|c|c|c|c|}
\hline & $\begin{array}{c}\mathrm{Er} \\
\mathrm{T} / 1\end{array}$ & $\begin{array}{c}\mathrm{Lc} \\
\mathrm{G} / 1\end{array}$ & $\begin{array}{c}\mathrm{Hb} \\
\mathrm{g} / \mathrm{dl}\end{array}$ & $\begin{array}{c}\mathrm{Hc} \\
1 / 1\end{array}$ & $\begin{array}{c}\mathrm{Ns} \\
\%\end{array}$ & $\begin{array}{c}\mathrm{Nb} \\
\%\end{array}$ & $\begin{array}{c}\text { Eo } \\
\%\end{array}$ & $\begin{array}{c}\mathrm{Ba} \\
\%\end{array}$ & $\begin{array}{c}\mathrm{Ly} \\
\%\end{array}$ & $\begin{array}{c}\mathrm{Mo} \\
\%\end{array}$ \\
\hline $\mathrm{x}$ & 10.45 & $4.64^{\mathrm{d}}$ & $11.42^{\mathrm{e}}$ & $0.42^{\mathrm{f}}$ & 39.8 & $8.0^{\mathrm{g}}$ & 4.8 & 0.4 & 47 & 0 \\
\hline sum & 52.26 & 23.20 & 57.10 & 2.12 & 199 & 40 & 24 & 2 & 235 & 0 \\
\hline $\min$. & 8.86 & 3.2 & 9.2 & 0.36 & 35 & 7 & 2 & 0 & 39 & 0 \\
\hline $\max$ & 13.6 & 8.6 & 13.8 & 0.49 & 50 & 10 & 8 & 1 & 52 & 0 \\
\hline $\mathrm{SD}$ & 1.98 & 2.24 & 1.68 & 0.05 & 6.0 & 1.2 & 2.9 & 0.5 & 5.1 & 0 \\
\hline $\mathrm{SEM}$ & 0.88 & 1.00 & 0.75 & 0.02 & 2.6 & 0.5 & 1.3 & 0.2 & 2.3 & 0 \\
\hline
\end{tabular}

suggested that response of leukocytes in wild ruminants is lower than in the aforementioned farm animals (Wilson and Pauli 1982; Chapman and Chapman 1982; Hawkey et al. 1984).

Our previous studies in captured fallow deer ( $\mathrm{Cimbal}$ et al. 1986) showed significant increase in leukocytes (from average $4.25 \mathrm{G} / 1$ in April to $7.47 \mathrm{G} / 1$ in May) in females in advanced pregnancy, followed by their decrease after parturition (June - 4.33, September 4.53, and November $-4.28 \mathrm{G} / 1$ ). These findings require a more detailed study, particularly in close relation to hormonal activity during reproduction cycle (Ostró and Toropila $1995 \mathrm{a}, \mathrm{b})$.

In our study, contrary to the report of Wils on and Pauli (1982) on haematological profile in red deer, we did not confirm a higher percentage of neutrophils compared with that of lymphocytes. Similarly, we did not observe significant differences in percentual values of other granulocytes. i.e. Eo, $\mathrm{Ba}$, and Mo that were similar to those found in domesticated animals.

Our previous studies ( $\mathrm{Cimb}$ al et al. 1986) revealed that the period of parturition in female fallow deer (June) was characterized by an increase in percentage of eosinophils (in average to $17.67 \%$ ), decrease in percentage of segmented (from average $66.17 \%$ in May to 36.33 $\%$ in June) and band (form $0.67 \%$ in May to $0.33 \%$ in June) neutrophils, and increase in percentage of lymphocytes (from $29.33 \%$ in May to $44.33 \%$ in June). During the following period we observed continuous recovery of these indices to the values found before parturition. At the same time, a decrease in leukocyte counts was found in the young in the

Table 9

Haematological profile in fallow deer (autumn 23. 9.-20. 12., $n=3$ )

\begin{tabular}{|l|c|c|c|c|c|c|c|c|c|c|}
\hline & $\begin{array}{c}\mathrm{Er} \\
\mathrm{T} / 1\end{array}$ & $\begin{array}{c}\mathrm{Lc} \\
\mathrm{G} / 1\end{array}$ & $\begin{array}{c}\mathrm{Hb} \\
\mathrm{g} / \mathrm{dl}\end{array}$ & $\begin{array}{c}\mathrm{Hc} \\
1 / 1\end{array}$ & $\begin{array}{c}\mathrm{Ns} \\
\%\end{array}$ & $\begin{array}{c}\mathrm{Nb} \\
\%\end{array}$ & $\begin{array}{c}\mathrm{Eo} \\
\%\end{array}$ & $\begin{array}{c}\mathrm{Ba} \\
\%\end{array}$ & $\begin{array}{c}\mathrm{Ly} \\
\%\end{array}$ & $\begin{array}{c}\text { Mo } \\
\%\end{array}$ \\
\hline $\mathrm{x}$ & $8.38^{\mathrm{c}}$ & $5.53^{\mathrm{d}}$ & $9.7^{\mathrm{e}}$ & $0.44^{\mathrm{f}}$ & 39 & $6.6^{\mathrm{g}}$ & 4.0 & 0.3 & 49 & 1 \\
\hline sum & 25.14 & 16.60 & 29.1 & 1.32 & 117 & 20 & 12 & 1 & 147 & 3 \\
\hline min. & 6.94 & 3.7 & 6.9 & 0.38 & 36 & 5 & 3 & 0 & 46 & 0 \\
\hline max. & 9.24 & 8.7 & 11.6 & 0.48 & 43 & 9 & 5 & 1 & 51 & 2 \\
\hline SD & 1.25 & 2.75 & 2.47 & 0.05 & 3.6 & 2.0 & 1.0 & 0.5 & 2.6 & 1 \\
\hline SEM & 0.72 & 1.58 & 1.42 & 0.03 & 2.0 & 1.2 & 0.5 & 0.3 & 1.5 & 0.5 \\
\hline
\end{tabular}


month of birth as compared with the next blood sampling in September (from 5.21 to $3.65 \mathrm{G} / 1$ ), increase in eosinophils from 0.7 to $3.0 \%$, decrease in segmented neutrophils from 66.0 to $41.5 \%$, and increase in lymphocytes from 29.42 to $53 \%$. We suggest that dynamics of aforementioned indices indicate their dependence on stage of pregnancy and age of newborns. These findings add to information published earlier (English and Lepherd 1981; Wilson and Pauli 1981; Rani and Apoloni 1998) on white blood picture differences between domesticated and wild ruminants.

Table 10

Haematological profile in fallow deer

(winter 21. 12.-20.3., $\mathrm{n}=8$ )

\begin{tabular}{|l|c|c|c|c|c|c|c|c|c|c|}
\hline & $\begin{array}{c}\mathrm{Er} \\
\mathrm{T} / 1\end{array}$ & $\begin{array}{c}\mathrm{Lc} \\
\mathrm{G} / 1\end{array}$ & $\begin{array}{c}\mathrm{Hb} \\
\mathrm{g} / \mathrm{dl}\end{array}$ & $\begin{array}{c}\mathrm{Hc} \\
1 / 1\end{array}$ & $\begin{array}{c}\mathrm{Ns} \\
\%\end{array}$ & $\begin{array}{c}\mathrm{Nb} \\
\%\end{array}$ & $\begin{array}{c}\text { Eo } \\
\%\end{array}$ & $\begin{array}{c}\mathrm{Ba} \\
\%\end{array}$ & $\begin{array}{c}\mathrm{Ly} \\
\%\end{array}$ & $\begin{array}{c}\text { Mo } \\
\%\end{array}$ \\
\hline $\mathrm{x}$ & $9.49^{\mathrm{c}}$ & $2.5^{\mathrm{d}}$ & $14.17^{\mathrm{e}}$ & $0.53^{\mathrm{f}}$ & 44.1 & $4.3^{\mathrm{g}}$ & 5.3 & 0 & $47^{\mathrm{h}}$ & $0.2^{\mathrm{ch}}$ \\
\hline sum & 75.96 & 20.0 & 113.40 & 4.27 & 353 & 35 & 43 & 0 & 376 & 2 \\
\hline $\min$. & 6.48 & 2.0 & 11.4 & 0.43 & 39 & 0 & 2 & 0 & 38 & 0 \\
\hline $\max$ & 12.40 & 3.1 & 15.2 & 0.58 & 50 & 8 & 18 & 0 & 52 & 1 \\
\hline $\mathrm{SD}$ & 1.99 & 0.39 & 1.23 & 0.04 & 3.7 & 2.9 & 5.9 & 0 & 4.4 & 0.4 \\
\hline $\mathrm{SEM}$ & 0.70 & 0.14 & 0.43 & 0.01 & 1.3 & 1.0 & 2.1 & 0 & 1.5 & 0.1 \\
\hline
\end{tabular}

Compared with the aforementioned information, in our study of haematological profile in fallow deer during the four seasons of the year, we found statistically significant differences $(\mathrm{P}<0.5)$ in mean values of erythrocytes, leukocytes, haemoglobin, haematocrit, band neutrophils, lymphocytes, and monocytes. These differences indicate the importance of transition period of feeding with changes in diet composition. Winter period is characterized by increased proportion of dry matter in the diet (nipping off tree twigs, feeding hay and other dried foods). Shift from winter to spring feeding is related to feeding green pasture grasses and winter corns. As in domesticated ruminants, it may be suggested that there is some period of adaptation of rumen micro-flora and micro-fauna. This period is frequently associated with diarrhoea, which may cause the changes in haematological profile (Kováč et al. 1992).

\section{Hematologické ukazovatele u danielej zveri}

Na základe doterajších poznatkov o hodnotách ukazovatelov hematologického profilu u danielej zveri sme študovali ich dynamiku (erytrocyty, leukocyty, hemoglobín, hematokrit, segmentované neutrofily, tyčinkové neutrofily, eozínofily, bazofily, lymfocyty, monocyty) u $11 \mathrm{ks}$ samčieho a $19 \mathrm{ks}$ samičieho pohlavia po riadnom a mimoriadnom odstrele v podmienkach zvernice v Rozhanovciach a vo zvernici Rožňava-Betliar.

Priemerné hodnoty pri porovnaní mladej danielej zveri (do veku 2 rokov) a dospelej danielej zveri (vo veku nad 2 roky) dosahovali pri: Er - 10,95 resp. 9,84 T/l; Lc - 3,98 resp. $3,55 \mathrm{G} / \mathrm{l} ; \mathrm{Hb}-13,12$ resp. $13,08 \mathrm{~g} / \mathrm{dl}$; Hk - 0,48 resp. 0,49 1/l; Ns - 39,5 resp. 40,5 \%; Nty 4,5 resp. $6,4 \%$; Eo - 5,2 resp. 3,7\%; Ba - 0 resp. 0,2; Ly - 49,3 resp. 49,3; Mo - 1,3 resp. 0,7. Zistené rozdiely v rámci skupín neboli štatisticky významné.

Obdobne štatisticky nevýznamné rozdiely sme zaznamenali pri posúdení vyššie uvedených ukazovateIov z pohladu rozdielneho pohlavia u danielej zveri do veku 2 rokov. $\mathrm{Na}$ rozdiel od uvedeného sme zistili pri porovnaní dospelých samcov a samíc danielej 
zveri štatisticky významné rozdiely $(\mathrm{P}<0,05)$ len pri $\mathrm{Hb}-11,07 \mathrm{resp} .13,89 \mathrm{~g} / \mathrm{dl}$ a pri $\mathrm{Hk}$ - 0,43 resp. $0.51 \mathrm{l} / \mathrm{l}$. Oproti vyššie popísaným poznatkom pri zhodnotení ukazovatelov hematologického profilu danielej zveri z pohIadu sezónnosti sme zistili štatisticky významné rozdiely $(\mathrm{P}<0,05)$ pri posúdení hodnôt Er: jar - jeseň (priemerné hodnoty 11,24 resp. 8,38 T/1), jar - zima (11,24 resp. $9.49 \mathrm{~T} / 1)$; Lc : jar - zima (3,97 resp. 2,5 G/1), leto zima (4,64 resp. $2,50 \mathrm{G} / 1)$ a jesen - zima (5,53 resp. 2,50 G/l); Hb : jar - leto (13,65 resp. $11,42 \mathrm{~g} / \mathrm{dl})$, jar - jeseň $(13,65 \mathrm{resp} .9,70 \mathrm{~g} / \mathrm{dl})$, leto - zima $(11,42$ resp. $14,17 \mathrm{~g} / \mathrm{dl})$ a jeseň - zima (9.70 resp. $14,17 \mathrm{~g} / \mathrm{dl}) ; \mathrm{Hk}:$ jar - leto $(0,50$ resp. $0,42 \mathrm{l} / \mathrm{l})$, leto - zima $(0,42 \mathrm{resp}$. $0,531 / 1)$, jeseň - zima $(0,44$ resp. $0,531 / 1)$; Nty : jar - leto $(2,8$ resp. $8,0 \%)$, jar - jeseň $(2,8$ resp. $6.6 \%$ ). leto - zima (8.0 resp. $4,3 \%$ ); Ly : jar - zima (53,1 resp. $47,0 \%$ ); Mo : jar zima (2,2 resp. $0,2 \%)$. Uvedené skutočnosti poukazujú zvlášt na prechodné obdobie v zložení prijímaného krmiva. Zimné obdobie je charakterizované vyšším podielom sušiny $v$ prijímanej potrave. ktorá pochádza $z$ ohryzu, prikrmovania senom, letninou. Prechod zo zimného obdobia na jarné súvisí so započatím príjmu zeleného porastu - tráv a ozimín. Tak ako u domácich prežúvavcov možno predpokladat so zretelom na zložitý žalúdok určité obdobie adaptácie bachorovej mikrofauny a mikroflóry, ktoré je často sprevádzané hnačkou, čo môže byt príčinou zmien $\mathrm{v}$ hodnotách ukazovatelov hematologického profilu.

\section{References}

ABAIGAR. T. 1993: Hematology and plasma chemistry values for captive dama gazelles (Gazella dama Mhorr) and cuviers gazelles (Gazella Cuvieri): age, gender, and reproductive status differences. J. Zoo Wildl. Med. 24: 177-184

CIMBAL, D. MAGIC, D., KOVÁČ, G. 1986: Priebeh adaptácie danielej zveri gyulajskej proveniencie v podmienkach ÚZ Rozhanovce. Folia Venatoria 16: 51-82

ENGLISH, A. W., LEPHERD, E. E. 1981: The haematology and serum biochemistry of wild fallow deer (Dama dama) in New South Wales. J.Wildl. Dis. 17: 289-295

HAWKEY, C. M., HART, M. G., FITZGERALD, A. K. 1984: Haematological values in mouflon (Ovis musimon): influence of age, sex, season and vitamin E status. Res. Vet. Sci. 36: 37-42

CHAPMAN. D. I. 1977: Comparative clinical haematology. Eds R. K. Archer and L. B. Jeffcott. Oxford, Blackwell Scientific Publications 1977: 345-364

CHAPMAN. D. I., CHAPMAN, N. G. 1982: Some haematological data of fallow deer (Dama dama in England). Res. Vet. Sci. 33: 205-207

JELÍNEK. P.. ILLEK, J., HELANOVÁ, I., FRAIS, Z. 1984: Biochemical and hematological values of the blood in rams during rearing. Acta vet. Bmo 53: 143-150

KOCAN, A. A.. GLENN, B. L., THEDFORD, T. R., DOYLE, M. A., WALDRUP, K.. KUBAT, G., SHAW, M. G. 1981: Effects of chemical immobilization on heamatologic and serum chemical values in captive white-tailed deer. JA VMA 179: 1153-1156

KOVÁČ, G.. PROSBOVÁ, M., BLAŽOVSKÝ, J.. REICHEL, P. 1986: Preventívna veterinárna medicína. Príroda. Bratislava: 386

KOVÁČ, G.. SEIDEL, H., MUDROŇ, P. 1992: Supplies of infusoria and blood plasma levels of vitamin $B_{12}$ in heifers during the transitional period. Proceedings from XVII. World Buiatric Congress. St. Paul, Minnesota, August 31 - September 4, Volume 3: 330-335

LEGATH, J.. MLYNARĆÍKOVÁ. H., ŠVICKÝ. E., LENHARDT, L., KAĆMÁR, P., BEÑOVÁ. K., KOVÁČ, G. 1996: Acute oral toxicity of the herbicide Burex Eko in pheasants. Vet.Med.- Czech. 41: 367-371

MAUTZ, W. W., SEAL, U. S., BOARDMAN, C. B. 1980: Blood serum analyses of chemically and physically restrained white-tailed deer. J. Wildl. Manage. 44: 343-351

MLYNARCíKOVÁ, H., LEGÁTH. J., DUDRÍKOVÁ, E., PORÁČOVÁ, J., KOVÁĆ, G. 1995: Biochemical aspects of toxic effects of supermethrin in the conditions of chronic 140- day avian reproductive test. Vet.Med.Czech. 40: 195-199

OSTRÓ. A.. TOROPILA, M. 1995a: Glukokortikoidy v krvi matky, plodovej vode. krvi z pupočníkových ciev a estriol v plodovej vode u žien s EPH gestózou. Slov. gyn. a pôrod. 2: 3-6

OSTRÓ, A.. TOROPILA, M. 1995b: Glukokortikoidy v krvi matky, v krvi z pupočníkových ciev a v plodovej vode u žien s prolongovanou graviditou. Slov. gyn. a pôrod. 2: 11-13

RANDI, E.. APOLLONIO, M. 1988: Low biochemical variability in European fallow deer (Dama dama L.): natural bottlenecks and the effects of domestication. Heredity 61: 405-410 
RIETKERK, F. E., DELIMA. E. C., MUBARAK. S. M. 1994: The hematological profile of the mountain gazelle (Gazella gazella): variations with sex, age, capture method, season and anesthesia. J. Wildl. Dis. 30: 69-76

SILVA, I. D.. KURUWITA. V. Y. 1993a: Hematology, plasma, and serum biochemistry values in free-ranging elephants (Elephas maximus ceylonicus) in Sri Lanka. J. Zoo Wildl. Med. 24: 434-439

SILVA, I. D., KURUWITA, V. Y. 1993b: Hematology, plasma, and serum biochemistry values in domesticated elephants (Elephas maximus ceylonicus) in Sri Lanka. J. Zoo Wildl. Med. 24: 440-444

SLANINA, L.., DVOŔÁK, R., BARTKO, P., HANÁK, J., HOFÍREK, B., LEHOCKÝ, J., ZENDULKA, I., 1993 : Veterinárna klinická diagnostika vnútorných chorôb. Príroda. Bratislava: $389 \mathrm{p}$.

VÁHALA, J., KAŠE, F., RYDER, O. A. 1994: Haematological and biochemical values of the blood and blood serum of captive northern white rhinoceroses (Ceratotherium simum cottoni). Acta vet. Brno. 63: 99-102

VRZGULA. L., KOVÁĆ, G. et al. 1991: Metabolic disorders and their prevention in farm animals. Elsevier Amsterdam: $390 \mathrm{p}$.

WILSON, P. R., PAULI, J. V. 1982: Blood constituents of farmed red deer (Cervus elaphus): I. Haematological values. N. Z. vet. J. 30: 174-176

WOLKERS, H., WENSING, T., SCHONEWILLE, J. T. 1996: Effect of undernutrition on haematological and serum biochemical characteristics in red deer (Cervus elaphus). Can.J.Zool. 72: 1291-1296

Address for correspondence:

Prof. MVDr. G. Kováč, DrSc.

University of Veterinary Medicine

Komenského 73

SK-041 81 Košice

Slovak Republic

Phone: 421956338520

Fax: 421956323666

E-mail: kovacg@vsvnov.uvm.sk 